\title{
INFLUENCE OF SOIL PH ON SOLUBILITY AND LEACHABILITY OF HEAVY METALS FROM SPENT ENGINE OIL POLLUTION
}

\author{
EBULUE, M.M.
}

Pollution and Environmental Biotechnology Research Unit, Department of Biochemistry, Paul University, Awka. Anambra State, Nigeria.

\section{Email:ebulvemm801f@yahoo.com}

\section{ABSTRACT}

The influence of soil $\mathrm{pH}$ on solubility and leachability of heavy metals (Fe, Cd, Cu, Mn, $\mathrm{Ni}$, $\mathrm{Pb}$ and $\mathrm{Zn}$, and $\mathrm{Ba}$ ) from spent engine oil pollution was investigated to estimate the level of toxicity on soil ecosystem. The result from flame atomic absorption spectrophotometer (FAAS) analysis revealed that at increasing acidity arising from increasing concentrations of spent engine oil there was increase in the solubility and leachability of heavy metals. The significant increase $(\mathrm{p}<0.05)$ in total petroleum hydrocarbon (TPH) from $2.60 \pm 0.00$ to $5.10 \pm 0.00$ across days-zero to -28 at $1.0-3.5 \%$ contamination increased the acidity from $\mathrm{pH} 5.4 \pm 0.00$ to $3.1 \pm 0.00$. At this $\mathrm{pH}$ range of $5.4-3.1$ across $2.0-3.5 \%$ pollution after 28 days exposure, the ppm of metal concentrations left are: Fe reduced from $6.02 \pm 0.01$ to $4.91 \pm 0.00, \mathrm{Mn}, 14.2 \pm 0.00$ to $10.6 \pm 0.05, \mathrm{Zn}, 9.8 \pm 0.03$ to $7.6 \pm 0.11, \mathrm{Cr}, 1.01 \pm 0.00$ to $1.00 \pm$ $0.00, \mathrm{Ni}, 0.01 \pm 0.00$ to $0.00 \pm 0.00$. Cadmiun (Cd), Lead (Pb) and Barium (Ba) which were not found in the soil were introduced from spent engine oil and are reduced as follows: $\mathrm{Cd}, 0.70 \pm 0.00$ to $0.4 \pm 0.01, \mathrm{~Pb}, 0.61 \pm 0.00$ to $0.55 \pm 0.00$ and $\mathrm{Ba} 9.40 \pm 0.00$ to $8.2 \pm 0.00$. Leachate test analysis (TCLP) at $2.0 \%$ pollution, $\mathrm{pH} 4.2, \mathrm{Cd}, \mathrm{Cr}, \mathrm{Pb}$ and Ba leached, while $\mathrm{Fe}, \mathrm{Mn}$ and $\mathrm{Ni}$ did not. Spent engine oil is considered toxic when the leaching test (TCLP) shows that the extracted hazardous metals exceeded the regulatory limit which is in (ppm) for: arsenic (5), barium (100), cadmium (1), chromium (5), lead (5), and silver (5). 


\section{INTRODUCTION}

Several abuses from anthropogenic means has made the soil to be the first line of recipient of oil pollution such as petroleum (crude oil) and petroleum-byproducts (spent engine oil), dumping of wastes and other contaminating substances (Ebulve et al., 2017; Osam, 2011 ; Nwaugo et al., 2006, 2009).

Soil $\mathrm{pH}$ is a physical property and an important parameter to monitor especially during the emergence of xenobiotic. It refers to acidity or alkalinity, which is a measure of hydrogen ion concentration $\left[\mathrm{H}^{+}\right]$in the soil; and it is defined by the equation; $\mathrm{pH}=-\log \left[\mathrm{H}^{+}\right]$. Soil with a large hydrogen ion concentration is acidic i.e., low $\mathrm{pH}$, and this acidity increases the solubility of elements which increases their mobility, lability and possibility of leaching into ground water; while soil with low hydrogen ion concentration is basic, i.e., high $\mathrm{pH}$ with a low probability of leachability of cations.

Oil prevents machines from frictional forces which could arise during operations (tear and wear). Many chemicals were developed to increase the performance and efficiency of engine oil and these chemicals are called lubricant additives. These additives are sources of contaminant and toxicity when spent engine oil is discharged on soil ecosystem. According to (ATSDR, 1997) spent engine oil, which is also known as used mineral-based oil, is a brown-to-black liquid produced when new mineral-based crankcase oil is subjected to high temperature and high mechanical strain.
Heavy metals are natural constituents of soil when they exist in normal levels, but they are considered pollutants when their

levels exceed permissible concentrations or when they are accumulated in soil. Toxic heavy metals that enter ecosystems lead to bioaccumulation and geoaccumulation (Udousoro et al., 2010) and their entry is through; disposal of spent engine oil, fertilizer application, atmospheric deposition, use of agrochemicals and organic wastes and inorganic pollutants. The constituents of spent engine oil are heavy metals such as lead, zinc, chromium, cadmium, arsenic and heavy polycyclic aromatic hydrocarbons which may cause chronic toxicity and carcinogenicity (Cosmacini, 1988; Ebulue et al., 2017). Therefore, discarding spent engine oil on soil releases different heavy metals which augment the naturally occurring ones in the soil, and this can be bio-transformed into aqueous phase by bacterial activity.

This change of heavy metals into aqueous phase which is $\mathrm{pH}$ dependent increases mobility and leachability of the metals into the soil. Thus soil $\mathrm{pH}$ is an important parameter that governs metal chemistry.

Spent engine oil contamination on soil affects adversely the exchangeable bases, $\mathrm{K}^{+}, \mathrm{Na}^{+}, \mathrm{Ca}^{2+}$ and $\mathrm{Mg}^{2+}$, the cation exchange capacity (CEC) which is the ability of soil particles to hold cations; a development that portends a serious danger as the cations may leach to ground water and become biounavailable to plants. This may affect the fertility of agricultural soil and eventually the performance of crops that require 
these mineral elements for growth and crop yield.

\section{Research design}

This research was designed for a-fortytwo-day investigation in consideration of the volatility and biodegradability of hydrocarbons:

Day-zero

Day- 14

Day- 28 and

Day- 42;

Within which, the influence of $\mathrm{pH}$ on the solubility and leachability of heavy metals were evaluated.

\section{MATERIALS AND METHOD}

Determination of $\mathrm{pH}$ of spent engine oilcontaminated soil

Principle: Advanced Bench pH Meters 3510 is suitable for easy readout of $\mathrm{pH}$ and temperature "with a resolution of three decimal places and automatic or manual buffer selection. It is versatile and ideal for routine analysis.

Procedure: Soil inoculation was carried out by weighing $10 \mathrm{~g}$ of sieved soil sample into six different test tubes. To the first tube, $0.1 \mathrm{~g}$ of spent engine oil in $10 \mathrm{~g}$ soil sample (corresponding to $1.0 \%$ ), was added and mixed thoroughly with a steering rod. This procedure was repeated for $1.5,2.0,2.5,3.0$ and $3.5 \%$ with $20 \mathrm{ml}$ of de-ionized water added; and into the $7^{\text {th }}$ tube, the control, $20 \mathrm{ml}$ of de-ionized water only was added to $10 \mathrm{~g}$ soil and mixed thoroughly by hand. Into the homogenous slurry formed was immersed $\mathrm{pH}$ meter probe (Jenway model) and was allowed to stabilize at $25^{\circ} \mathrm{C}$. The $\mathrm{pH}$ values were then determined after calibration with buffer solution of $\mathrm{pH} 7.0$ and 4.0.

\section{Determination of total petroleum hydrocarbon (TPH)}

Principle: It is based on the estimation of the total petroleum hydrocarbon (TPH) in the soil with reference to the standard curve derived from fresh spent engine oil diluted with tolvene using the equation $y$ $=1.094 \mathrm{x}$; where $\mathrm{y}=$ absorbance and $\mathrm{x}=$ concentration.

Procedure: Total petroleum hydrocarbon content was determined gravimetrically by the method of Odu et al. (1989), to provide an estimate of the available total hydrocarbon with time. In this procedure, $20 \mathrm{ml}$ tolvene was added into six test tubes containing $10 \mathrm{~g}$ soils contaminated with different concentrations of spent engine oil: 1.0, 1.5, 2.0, 2.5, 3.0 and $3.5 \%$ $\mathrm{w} / \mathrm{w}$ (oil-soil mixture). Into the $7^{\text {th }}$ tube, the control, $20 \mathrm{ml}$ tolvene was introduced into $10 \mathrm{~g}$ of uncontaminated soil. After shaking for $30 \mathrm{~min}$, the liquid phase of the extract was measured spectrophotometrically at $420 \mathrm{~nm}$. The total petroleum hydrocarbon (TPH) in the soil was estimated with reference to the standard curve derived from fresh spent crankcase oil diluted with tolvene using the equation $y=$ 1.094x; where $y=$ absorbance and $x=$ concentration.

Determination of heavy metals in the spent engine oil; engine oil digestion

Principle: Heavy metal analysis was conducted using Varian AA240 Atomic Absorption Spectrophotometer according to the method of APHA 1995 (American Public Health Association). Atomic absorption spectrometer is based on the sample being aspirated into the flame and atomized when the AAS's light beam is directed through the flame into the monochromator and onto the detector that measures the amount of light absorbed by the atomized element in the flame. 
Procedure: Small amount of spent engine oil (about 2g) was placed inside digestion flask and $4 \mathrm{ml}$ of concentrated $1 \mathrm{~N} \mathrm{H}_{2} \mathrm{SO}_{4}$ was added, and a column was put at the top of the flask to remove acid vapour produced by refluxing for about $5 \mathrm{~min}$ at $440^{\circ} \mathrm{C}$. Thereafter, $10 \mathrm{ml}$ of $0.5 \mathrm{M}$ $\mathrm{H}_{2} \mathrm{O}_{2}$ was added and refluxed for $2 \mathrm{~min}$. When the solution was cooled, de-ionized $\mathrm{H}_{2} \mathrm{O}$ was added to make the volume of the solution $100 \mathrm{ml}$. The mixture was filtered with Whatman No.1 filter paper and became ready for the determination of heavy metals: $\mathrm{Fe}, \mathrm{Mn}, \mathrm{Zn}, \mathrm{Cr}, \mathrm{Cd}, \mathrm{Pb}$, $\mathrm{Ni}$ and $\mathrm{Ba}$ in the spent engine oil by flame atomic absorption spectrophotometer (FAAS).

Determination of heavy metals ( $\mathrm{Fe}, \mathrm{Mn}$, $\mathrm{Zn}, \mathrm{Cr}, \mathrm{Cd}, \mathrm{Pb}, \mathrm{Ni}$ and $\mathrm{Ba}$ ) in the spent engine oil-contaminated soil after 28 days exposure at $\mathbf{2 . 0}$ and $3.5 \%$ pollution and $\mathrm{pH} 4.2$ and 3.1

Principle: Heavy metal analysis in the spent engine oil contaminated soil was conducted using Varian AA240 Atomic Absorption Spectrophotometer according to the method of APHA 1995 (American Public Health Association). Atomic absorption spectrometer (AAS) is based on the sample being aspirated into the flame and atomized when the AAS's light beam is directed through the flame into the monochromator and onto the detector that measures the amount of light absorbed by the atomized element in the flame.

Procedure: The composite sample of spent engine oil which was obtained randomly from different mechanic villages was used to contaminate the soil at 2.0 and $3.5 \% \mathrm{w} / \mathrm{w}$ oil in soil. The mixture was digested with concentrated $1 \mathrm{~N}$ $\mathrm{H}_{2} \mathrm{SO}_{4}$, filtered with Whatman No.1 filter paper and $\mathrm{Fe}, \mathrm{Zn}, \mathrm{Pb}, \mathrm{Mn}, \mathrm{Cr}, \mathrm{Ba}, \mathrm{Cd}$ and
$\mathrm{Ni}$ were determined by flame atomic absorption spectrophotometer (FAAS).

Leachability test for heavy metals (Fe, $\mathrm{Mn}, \mathrm{Zn}, \mathrm{Cr}, \mathrm{Cd}, \mathrm{Pb}, \mathrm{Ni}$ and $\mathrm{Ba}$ ) in spent engine oil at $2.0 \%$ contamination, $\mathrm{pH} 4.2$

Principle: This analysis is based on the principle that leaching materials are transferred from a stabilized matrix to liquid medium such as water or solutions. The TCLP extraction is expected to test contaminated soils and sediments, sludges, petroleum contaminated soils, waste oils or fuels. Samples passing the test are expected to be stable for many years when placed in a landfill.

TCLP extract preparation: Extract the solid sample, separate the liquid extract from the solid sample by filtration. The extracted solution was then analyzed for leachable metal using ICP-MS

Procedure: The toxicity characteristics leaching procedure (TCLP) is a leaching test used to determine the content of heavy metals in contaminated materials (US EPA Method 1311, 1990).The Inductively Coupled Plasma-Atomic Emission Spectrometry (ICP-MS) was used for analysis of total metals and TCLP extract.

TCLP procedure which is a soil sample extraction method for chemical analysis employed to simulate leaching through a landfill comprises four procedures: sample preparation for leaching, sample leaching, preparation of leachate for analysis and leachate analysis. In this procedure, the $\mathrm{pH}$ of the sample is first established and then leached with acetic acid /sodium hydroxide solution at a 1:20 mix of sample to solvent.

The spent engine oil collected from automechanic workshop was digested with $1 \mathrm{~N} \mathrm{HNO}_{3}$ acid and $0.5 \mathrm{M} \mathrm{H}_{2} \mathrm{O}_{2}$ hydrogen peroxide; the hot block digestion 
procedure was used to analyze metals using atomic absorption spectrophotometer (AAS) (Konokpa et al., 1999).

The spent engine oil is considered toxic when the leaching test shows that the extracted hazardous metals exceeded the regulatory limit which is in (ppm) for: arsenic (5), barium (100), cadmium (1), chromium (5), lead (5), and silver (5) (US EPA Method 1311, 1990).

\section{Statistical analysis}

The results were expressed as mean \pm standard error mean (SEM). All results were compared with respect to the control. Comparisons between the concentrations and control were made by using Statistical Package for Social Sciences (SPSS) version 20 and Analysis of Variance (ANOVA). Differences at $(p<$ $0.05)$ were considered significant.

\section{RESULT}

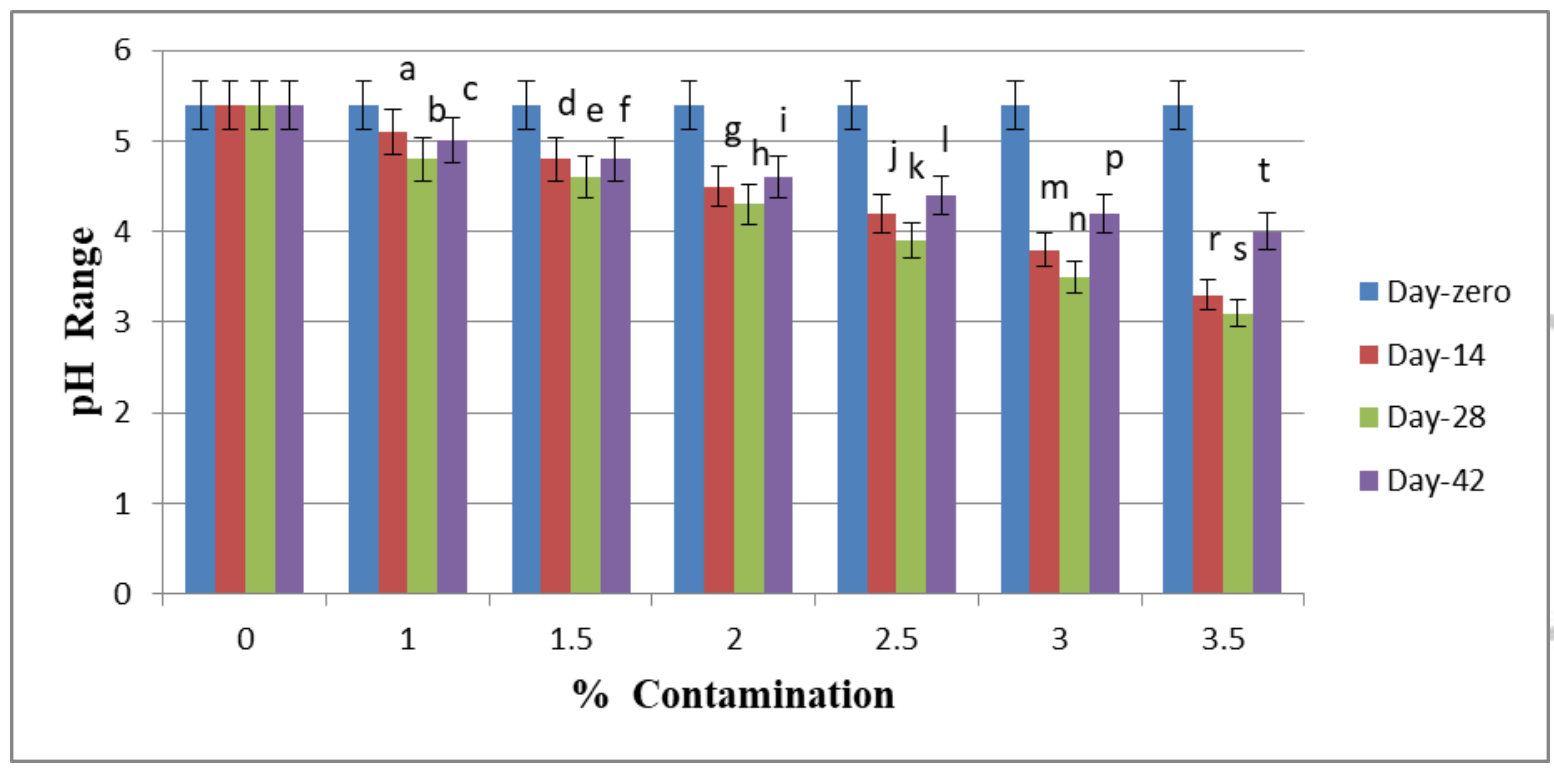

Fig. 1: pH of soil contaminated with spent engine oil, comparison between groups: Bars with different letters differ significantly $(\mathbf{p}<0.05)$. 


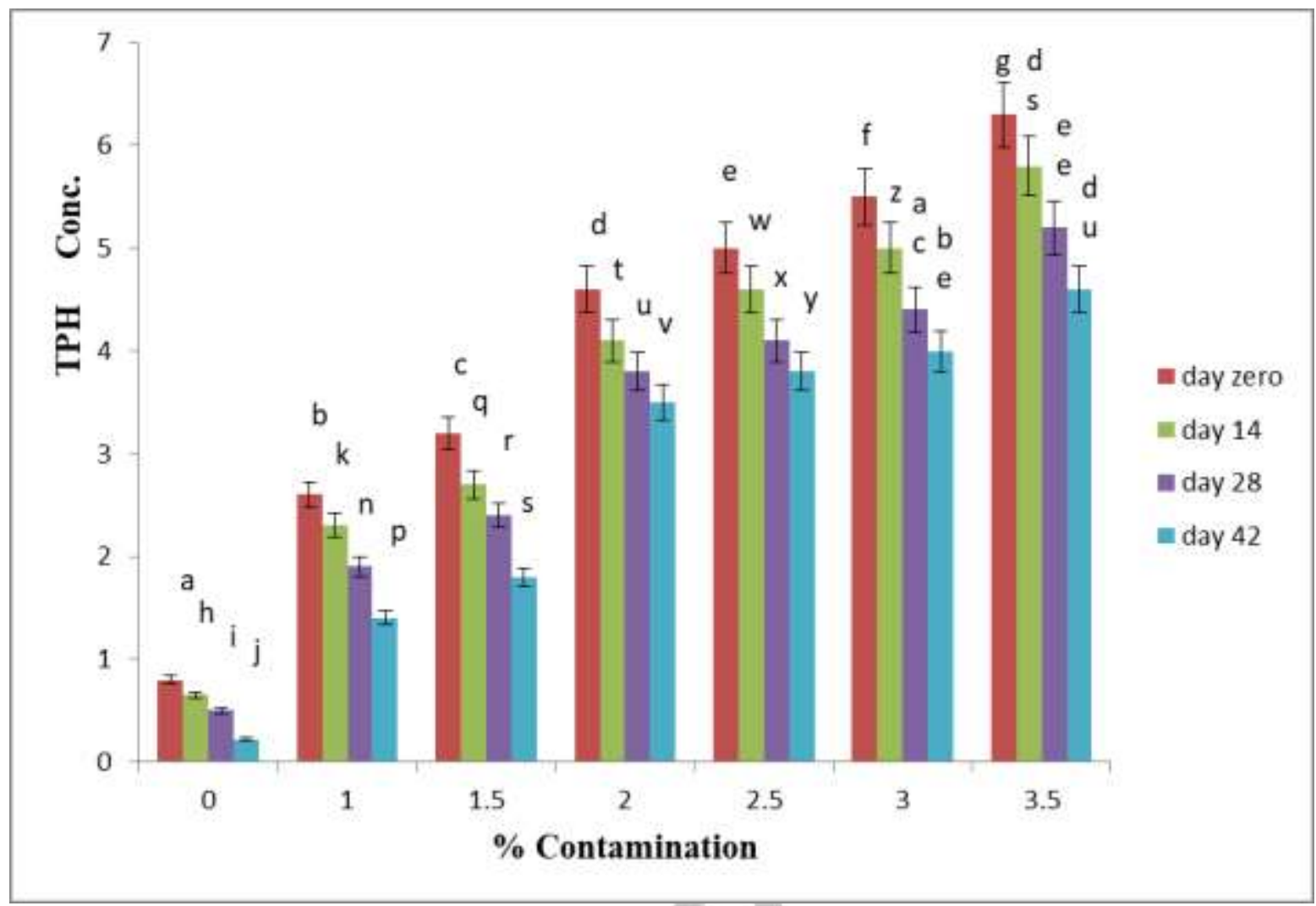

Fig. 2: Total petroleum hydrocarbon (TPH) of the spent engine oil-contaminated soil, Comparison between groups: Bars with different letters differ significantly $(\mathbf{p}<0.05)$.

Table 1: Analysis of heavy metal concentrations in spent engine oil Parameter ppm

$\mathrm{Fe}$

$6.05 \pm 0.00$

$\mathrm{Zn}$

$19.20 \pm 0.05$

$\mathrm{Pb}$

$0.86 \pm 0.00$

$\mathrm{Mn}$

$9.70 \pm 0.02$

$\mathrm{Cr}$

$1.05 \pm 0.00$

$\mathrm{Ni}$

$0.02 \pm 0.00$

$\mathrm{Ba}$

$11.80 \pm 0.01$

$\mathrm{Cd}$

Results are expressed as mean \pm SD $n=3$

Table 2: Concentration of heavy metals in soil and pH after 28 days exposure at 2.0 and $3.5 \%$ (w/w) spent engine oil contamination

Fe $\quad$ Mn $\quad$ Zn $\quad$ Cr (ppm)

\begin{tabular}{|c|c|c|}
\hline pH 5.4 (control) & $6.02 \pm 0.01^{\mathrm{a}}$ & $14.2 \pm 0.00^{\mathbf{b}}$ \\
\hline
\end{tabular}




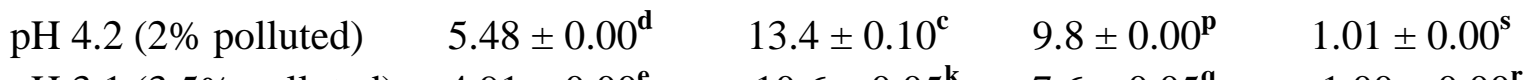

pH $3.1(3.5 \%$ polluted $) \quad 4.91 \pm 0.00^{\mathrm{e}} \quad 10.6 \pm 0.05^{\mathrm{k}} \quad 7.6 \pm 0.05^{\mathrm{q}} \quad 1.00 \pm 0.00^{\mathrm{r}}$

$\begin{array}{llll}\text { Cd } & \text { Pb } & \text { Ni } & \text { Ba (ppm) }\end{array}$

\begin{tabular}{lcccc}
\hline pH 5.4 (control) & $0.00 \pm 0.00^{\mathbf{n}}$ & $0.00 \pm 0.00^{\mathbf{f}}$ & $0.01 \pm 0.00$ & $0.00 \pm 0.00^{\mathbf{t}}$ \\
pH 4.2 (2\% polluted) & $0.70 \pm 0.05^{\mathbf{j}}$ & $0.61 \pm 0.00^{\mathbf{l}}$ & $0.02 \pm 0.00$ & $9.4 \pm 0.00^{\mathbf{g}}$ \\
pH 3.1 (3.5\% polluted) & $0.48 \pm 0.01^{\mathbf{h}}$ & $0.55 \pm 0.00^{\mathbf{m}}$ & $0.00 \pm 0.00$ & $8.2 \pm 0.01^{\mathbf{v}}$
\end{tabular}

Results are expressed as mean $\pm S D ; n=3$

Values with different letter superscripts in a column differ significantly at $(\mathbf{p}<0.05)$.

Table 3: Leachability test for heavy metals ( $\mathrm{Fe}, \mathrm{Mn}, \mathrm{Cr}, \mathrm{Cd}, \mathrm{Pb}, \mathrm{Ni}$ and $\mathrm{Ba}$ ) in spent engine oil at $2.0 \%$ contamination, $\mathrm{pH} 4.2$

\begin{tabular}{lccc} 
Parameter & $\begin{array}{c}\text { Total }(\mathbf{T}) \\
(\mathbf{p p m})\end{array}$ & $\begin{array}{c}\text { Leached (TCLP) } \\
(\mathbf{p p m})\end{array}$ & $\begin{array}{c}\text { Ratio [TCLP] } /[\mathrm{T}] \\
(\% \text { extracted })\end{array}$ \\
\hline $\mathrm{Cd}$ & $1.20 \pm 0.02$ & 0.10 & 8.30 \\
$\mathrm{Ni}$ & $0.02 \pm 0.00$ & - & - \\
$\mathrm{Cr}$ & $1.05 \pm 0.00$ & 0.20 & 19.04 \\
$\mathrm{~Pb}$ & $0.86 \pm 0.00$ & 0.20 & - \\
$\mathrm{Mn}$ & $9.70 \pm 0.02$ & - & 82.25 \\
$\mathrm{Ba}$ & $11.80 \pm 0.01$ & 8.30 & - \\
$\mathrm{Fe}$ & $6.05 \pm 0.00$ & - &
\end{tabular}

Regulatory limit in ppm for: As (5), Ba (100), Cd (1), Cr (5), Pb (5), Ag (5).

Results are expressed as mean \pm SD $n=3$

\section{DISCUSSION}

Soil $\mathrm{pH}$ is an important physical property to monitor especially during hydrocarbon impact from petroleum products. From this investigation, the positive correlation between the $\mathrm{pH}$ of the soil and the amount of spent engine oil impacted may be an implication that spent oil pollution led to a reduction in soil $\mathrm{pH}$. The increased acidity increased the solubility of elements which increased their mobility, lability and probability of leaching into ground water. The lowered $\mathrm{pH}$ reflected accelerated metabolism and accelerated demand for electron acceptors thus creating a reducing environment. This could be attributable to microbial metabolism of the hydrocarbon 
present in the spent engine oil contaminated soil, which consequently gave rise to the production of organic acids that resulted to the increase in the acidity of the affected ecosystem. This is replete with the report of Osuji and Nwoye (2007), Osam et al. (2013). This increase in acidity would likely affect plant growth, microbial succession and metabolism.

Toxicity characteristics leaching procedure (TCLP) for heavy metals Cd, $\mathrm{Cr}, \mathrm{Pb}, \mathrm{Mn}, \mathrm{Ba}, \mathrm{Ni}$ and $\mathrm{Fe}$ in spent engine oil was explored and found that leaching paralleled the degree of pollution and acidity. The result of this study demonstrated that a $\mathrm{pH}$ decrease for instance, from 5.4 - 3.0 enhanced such effects. Thus, soil $\mathrm{pH}$ governs the rate of metal leachates.

The most relevant findings in this study are that of all the toxic heavy metals that leached in this spent engine oil analysis fell below their regulatory limits. This toxicity characteristic leaching procedure (TCLP) result is highly rewarding as it has demonstrated that these metals, though could be hazardous, but hence they fell below their regulatory limits in ppm: As (5), Ba (100), Cd (1), Cr (5), Pb (5), Ag (5) could still be tolerated by plants. This is in consonance with the work of Kreith, (1994); and Steinhart et al. (2002).

\section{REFERENCES}

TSDR (Agency for Toxic Substances Disease Registry, (1997). Toxicology Profile for used Mineral-Based Crankcase Oil. Department of Health and Human Services, Public Health Services Press, Atlanta, GA, USA. 8: 83 - 84.
Cosmacini, E. D., Cotia, L. P., Leoni, R. J. (1988). The toxicity characteristics leaching procedure (TCLP) extraction in evaluation of heavy metals and total organic volatile contaminants in used engine oil and sludges. Ars Separatoria Złoty potok, Poland, 3, 251 - 260.

Ebulue, M. M., Nwodo, O. F. C., Onwurah, I. N. E., Uwakwe, A.A. and Wegwu, M. O. (2017). Enzyme-based assay for toxicological evaluation of soil ecosystem polluted with spent engine oil. International Journal of Innovative Science, Engineering and Technology, 4 Issue 7: 178 - 189.

Konopka, A., Zakharova, T., Bischoff, M., Oliver, L., Nakatsu, C. and Turco, R. F. (1999). Microbial biomass and activity in lead-contaminated soil. Applied Environmental Microbiology, 65: 22562259.

Kreith, F. (1994). Editor. Handbook of solid waste management. New York: McGrawHill, Inc. State of Utah, DEQ. (1997). Used Oil Management Rules.

augo, V. O, Onyeagba, R. A., Azu, N. and Nwachukwu, N. C. (2006). Bacteriological quality of cercariae (Schistosoma haematobium) infested abandoned quarry pits water. Journal of Science Engineering Technology, 13(2): 6697-6706.

Nwaugo, V. O., Onwuchekwa, I. S., Ogbonna, C. and Onyeagba, R. A. (2009). Assessment of physicochemical and biological indices of fluvial deposits in abandoned mine pits in Ishiagu, South Eastern Nigeria. Nigerian Journal of Microbiology, 23 (1):18(30-38). 
C. T. I., Nwoboshi, L. C. and Esuroso, O. F. (1989). Environmental Studies of Soils and Vegetation of Nigerian Agip Oil Company operation areas. In: Proceedings of an International Seminar on the Petroleum Industry and Nigerian Environment. NNPC, Lagos, Nigeria, 274283.

am, M. U. (2011). Evaluation of the Efficacy of Selected Wild-Type Legumes in the Remediation of Crude Oil Contaminated Agricultural Soils. Ph.D Dissertation, Biochemistry Department, University of Port Harcourt, Nigeria.

sam, M. U., Wegwu, M. O. and Ayalogu, E. O. (2013). Soil pH, moisture content and some macro non-metallic elements in crude oil contaminated soils remediated with some wild-type legumes. International Journal of Engineering Science Invention, 2: 54-59.

L. C. and Nwoye, I. (2007). An appraisal of the impact of petroleum hydrocarbons on soil fertility: the Owaza experience. African Journal of Agricultural Resources, 2(7): 318- 324.

Steinhart, H., Käcker, T., Meyer, S. and Biernoth, G. (2002). How much analytical work do we need? In: Stegmann, R., Brunner, G., Calmano, W., Matz, G., edtrs. Treatment of contaminated soil: fundamentals, analysis, applications. New York:Springer, p. 37-47.

dousoro, I.I., Umoren, I.U. and Asuquo, E.O. (2010). Survey of some heavy metal concentrations in selected soils in South Eastern parts of Nigeria. World Journal Applied Science and Technology, 2(2):139 - 14.
US EPA Method 1311 (1990). Toxicity characteristic leaching procedure (TCLP). 